\title{
OPTIMIZING THE ECOLOGICAL FUNCTIONS OF PUBLIC GREEN SPACE IN KLOJEN SUB-DISTRICT, MALANG CITY
}

Nurul Aini*, Rima Dewi Supriharjo**, Haryo Sulistyarso**

*) Master student, Department of Architecture, Faculty of Civil Engineering and Planning, Institut Teknologi Sepuluh Nopember, Indonesia

**) Lecturer, Department of Architecture, Faculty of Civil Engineering and Planning, Institut Teknologi Sepuluh Nopember, Indonesia

e-mail: ainiplanologi@gmail.com

\begin{abstract}
Malang city has a high level of construction development causing many conversions of green open space into developed areas. One region that has a lot of green open space conversion into developed areas is Klojen Sub-Distric. The converted area is used to built a shopping center, residential areas and regional government office. This causes some environmental degradation, including increasing of air temperature in Malang city and reduced ability of green open space to produce oxygen. The purpose of this research is to optimize the ecological functions of green open space in Klojen Malang. The ecological functions that will be discussed are green open space as oxygen producer and as air temperature controller.

The approach used in this research is positivistic, as the basis of experimental studies which use quantitative methods to verify the research hypothesis. The research type is a combination of descriptive and quantitative using techniques such as mapping analysis, characteristics of plant components and softscape analysis, oxygen demand analysis, biomass analysis, inter polation analysis, the average daily air temperature analysis, scoring analysis and descriptive analysis of green open space optimization.

The results obtained in this research are to optimize the ecological function of green open space by adding 1216 trees, to increase frequency value and density. Criteria are suggested for the additional trees, to be suited to the characteristics of each open green space. Based on the optimization concept, the oxygen demand can be reduced by $42.3 \%$. Moreover, it can also reduce the air temperature of public green open space to a minimun ideal urban air temperature, which is $27,5^{\circ} \mathrm{C}$.
\end{abstract}

Keywords: air temperature, ecological functions, green open space, oxygen.

\section{INTRODUCTION}

Green open space is needed in a highly populated city because it is one of the important components in a city's ecosystem. Green open space is not only to improve the environmental condition of a city, but also to maintain the public welfare and improve the quality of city life (Hakim, 2012). Malang is a city with a 
high population growth of $9.3 \%$ per year and a total population of 1.175 .290 million. As a high population city, Malang's concern is with the existence of green open spaces, especially the public ones. However, according to the regional council of Wahana Lingkungan Hidup (Walhi) in east java, the area of remaining green open space is only $1.8 \%$ of $110.6 \mathrm{~km} 2$ of the city . This is due to a lot of conversion of green open space for shopping centers, residential, hotel and office complexes (Pridhita, 2012).

The conversion of green open space into developed land gives negative impacts on the environment. The environmental impact is the increase of air temperature that reach 11 degrees Celsius in the dry season. In 1997 the average air temperature in Malang was around 23.4 degrees Celsius. At the end of 2006 this increased to 24.2 degrees Celsius, and even once reached 33.5 degrees Celsius in the dry season. In 2007 the highest temperature reached 33.0 degrees Celsius and increased dramatically in 2008 to 34.0 degrees Celsius (Bintariadi, 2010). In addition, other impacts from the conversion of green open space are reduced oxygen producing ability that cause unmet needs of oxygen in Malang City. Malang city still needs 45.53 tons / day of oxygen.

This indicates that the green open space has not worked optimally in generating O2 (Sesanti, 2011). The environmental problems caused by conversion of urban green space should be overcome immediately. Therefore, a research to optimize the ecological functions of public green space in Klojen Sub-District of Malang City is necessary.

\section{THEORY AND RESEARCH METHODS}

Based on the definition of public green space from Fandeli (2004), Irwan (2005) and Spreiregen in Hakim (2012), public green open space is part of the urban space that is managed by local governments. Public green space functions as a protected area with a variety of plants that grow naturally or artificially and serves a meeting place for community to undertake activities together. According to Hakim (2012), Green Open Space is divided into two types, There are Green Space Preserve (RTHL) and Green Open Space Patronage (RTHB). In this research, the green spaces that will be studied are the areas that have a potential to be developed as a public green space for ecological functions. Therefore the type of green space that will be studied is Public Green Space Patronage. According to Hakim (2012) the types of RTHB consist of recreation and sports facilities, horticulture gardens, public cemetery, parks, urban forests, and the green line.

Every public green space has different characteristics. One of them can be seen from the characteristics of the soft scape and the plants components. According to Suharto in Abdillah (2005), the characteristic of softscape is the main material in public green space (vegetation), and the softscape that will be studied in this research are trees. Beside that, the characteristics of plant components according to Indriyanto (2005) can be seen from the eight parameters to describe a plant community. However, according to Global and Bhardwaj in Indriyanto (2005) and Kusmana in Indriyanto (2005), the description of a plant community basically just needs a minimum three kinds of quantitative parameters. These are density, frequency and dominance. 
These characteristics will support the ecological functions of public green space. According to Philip, Walker and Lanphear in Hakim (2012), Ebtessam (2011) and Hakim (2012), green open space has several ecological functions. In this research, the ecological functions of public green space that will be studied is public green space as an air temperature controller and as an oxygen producer.

\section{Research Methods}

The approach used in this research is the positivistic approach that displays the truth between correspondence and facts. A positivistic approach is used as the basis of experimental studies using quantitative methods to verify the research hypothesis. The type of this research is a combination of descriptive and quantitative. Descriptive method is used to identify the potential areas for public green space development in terms of ecological function, also the characteristics of public green space, including soft scape and plant communities characteristics. The analysis technique used are statistical descriptive analysis, mapping analysis, plant components analysis and soft scape characteristics analysis.

The quantitative descriptive methods are used to analyze the condition of oxygen and air temperature, and also to analyze the ecological functions of public green space in Klojen Subdistrict, Malang City. These methods describe the condition of the field descriptively, supported by numeral in interpreting any research objectives. The analysis techniques used are oxygen demand analysis, biomass analysis, interpolation analysis, the average daily air temperature analysis and scoring analysis. Techniques used to collect data are secondary survey and primary survey such as observations so the data is based on real facts.

\section{RESULTS AND DISCUSSION}

\section{Identification of Potential Areas for Public Green Space Development for Ecological Functions}

Klojen Subdistrict consists of 11 villages, but not all of these villages have green open spaace. There are 51 green open space in Klojen Subdistrict that lie in 10 villages. The green open spaces are public green spaces and non-public green spaces. In this research, the green open spaces that will be studied are the potential areas for public green space deleopment for ecological functions. Therefore, the green open space that will be studied must meet established criteria, including that green open space should be managed by the government and should be include in patronage green space.

Based on observations in the 51 green spaces in Klojen Subdistrict, 32 areas of green space met the two criteria. These 32 areas are managed by the government and are patronage green space. Potential areas for public green space development as ecologically functioning areas are shown in Figure 1.

Based on Figure 1, the type of public green space that is most commonly found is green line. There are 16 green line, while the type of public green space that is least commonly found in Klojen Subdistrict is nursery. 


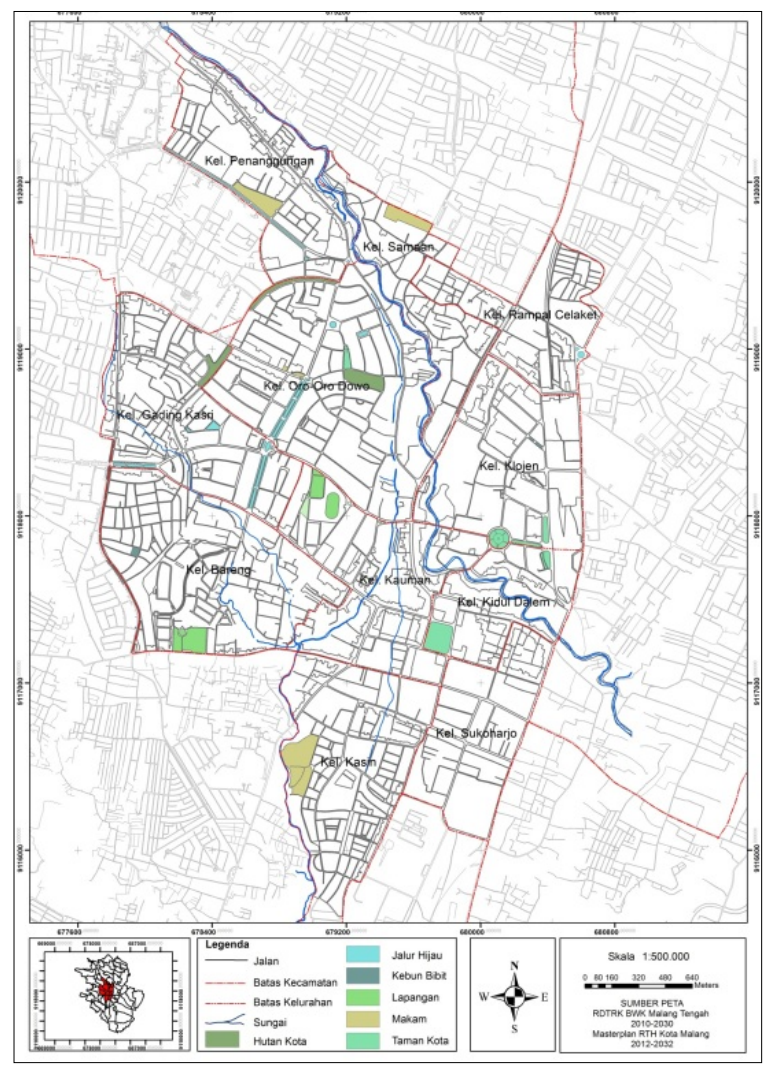

Figure 1. Distribution of Public Green Space in Klojen by Type

Source: field survey, 2015

\section{Characteristic Identification of Potential Areas for Public Green Space Development in terms of Ecological Function}

Public green space in Klojen has different characteristic. To see the differences, it is necessary to identify every public green space in Klojen Sub-District. Characteristics of public green space can be seen from the soft scape and plant communities characteristics of public green space. The soft scape are vegetation that grows in green open space, such as trees, shrubs, bushes, grasses and cover crops. In accordance with the limits of discussion, soft scape that will be studied in this research is stands of trees vegetation. So the stratum that will be examined is the tree stands with strata A, B, C and D.

Based on identified characteristics of the soft scape, there are different characteristics of vegetation in every type of public green space. Public green space which has a large area, such as urban forests, cemeteries and parks, have more diverse vegetation. Vegetation on these public green space generally consists of vegetation strata $B, C$ and $D$. Other types of green space that have less area will typically only consist of stratum C and stratum D. Different leaf shapes can be found in every public green space in Klojen subdistrict; diameter and crown width is also very varied according to the type of vegetation stratum. The stratum B 
vegetation generally has a diameter and crown width higher than the strata C and D vegetation.

Beside the characteristics of soft scape, identification also determined the characteristics of plant communities in public green space. A description of plant community characteristics can be known in quantitative terms using some parameters. This research used three parameters to describe the characteristics of vegetation in open green space. Tabel 1 is the results of plant communities analysis in each Public Green Space in Klojen Sub-District Malang city.

Tabel 1. Characteristics of Plant Communities in Klojen Sub-District Malang City

\begin{tabular}{|c|c|c|c|c|c|}
\hline \multirow{2}{*}{ Public Green Space } & \multirow{2}{*}{ Density } & \multirow{2}{*}{$\begin{array}{c}\text { Freque } \\
\text { ncy }\end{array}$} & \multicolumn{3}{|c|}{ Stratum Dominance Index } \\
\hline & & & B & $\mathbf{C}$ & $\mathbf{D}$ \\
\hline Taman Alun-alun Tugu & 40,9 & 0,73 & 0,00 & 0,04 & 0,64 \\
\hline Taman Ronggowarsito & 28,8 & 0,45 & 0,04 & 0,34 & 0,04 \\
\hline Taman Kertanegara & 32,1 & 0,57 & 0,04 & 0,34 & 0,04 \\
\hline Taman Trunojoyo & 45,3 & 1,00 & 0,09 & 0,39 & 0,01 \\
\hline Taman Dr. Sutomo & 33,3 & 1,00 & 0,00 & 0,36 & 0,16 \\
\hline Taman Panglima sudirman & 28,3 & 0,78 & 0,00 & 0,00 & 0,91 \\
\hline Lapangan dinas pertanian & 26,6 & 0,87 & 0,00 & 0,87 & 0,00 \\
\hline Taman Median JA Suprapto & 71,0 & 0,43 & 0,04 & 0,26 & 0,09 \\
\hline Makam Kasin & 30,0 & 0,96 & 0,09 & 0,31 & 0,02 \\
\hline Makam Samaan & 19,2 & 0,46 & 0,08 & 0,32 & 0,02 \\
\hline Kebun Bibit garbis & 22,2 & 0,52 & 0,00 & 1,00 & 0,00 \\
\hline Taman Alun-alun Merdeka & 18,0 & 0,78 & 0,07 & 0,51 & 0,00 \\
\hline Taman Choiril Anwar & 300,0 & 0,58 & 0,00 & 0,00 & 1,00 \\
\hline Kompleks GOR gajayana & 11,0 & 1,00 & 0,04 & 0,53 & 0,00 \\
\hline Taman Median Basuki Rahmad & 54,2 & 0,26 & 0,00 & 0,00 & 1,00 \\
\hline Taman Adipura/Arjuno & 125,0 & 0,83 & 0,00 & 0,00 & 1,00 \\
\hline Taman Melati & 41,7 & 1,00 & 0,00 & 0,00 & 1,00 \\
\hline Jalur Tengah Galunggung & 64,3 & 0,67 & 0,12 & 0,32 & 0,01 \\
\hline Taman Jalur Tengah Dieng & 48,7 & 1,00 & 0,05 & 0,50 & 0,00 \\
\hline Taman Wilis & 37,5 & 0,85 & 0,02 & 0,75 & 0,00 \\
\hline Hutan Kota Kediri & 248,3 & 0,86 & 0,02 & 0,61 & 0,01 \\
\hline TMP Pahlawan Trip & 11,4 & 0,91 & 0,00 & 0,03 & 0,67 \\
\hline Taman Jalur Tengah Ijen & 25,2 & 0,27 & 0,00 & 0,51 & 0,08 \\
\hline Taman Merbabu & 153,6 & 0,48 & 0,00 & 0,30 & 0,20 \\
\hline Hutan Kota Malabar & 205,8 & 0,81 & 0,05 & 0,24 & 0,08 \\
\hline Taman Simpang Balapan & 33,3 & 0,92 & 0,00 & 0,00 & 1,00 \\
\hline Taman TGP & 116,7 & 0,83 & 0,02 & 0,42 & 0,05 \\
\hline Hutan Kota Jakarta & 84,7 & 1,00 & 0,01 & 0,59 & 0,02 \\
\hline Taman Jalur Tengah Veteran & 66,8 & 0,81 & 0,06 & 0,32 & 0,04 \\
\hline TMP Suropati & 25,6 & 0,54 & 0,02 & 0,11 & 0,27 \\
\hline Taman Segitiga Pekalongan & 8,3 & 0,76 & 0,00 & 1,00 & 0,00 \\
\hline Taman Bundaran Bandung & 100,0 & 0,33 & 0,00 & 0,00 & 1,00 \\
\hline
\end{tabular}

Based on the analysis of plant communities, the different characteristics of plant communities in every public green space can be known. It depends on the area's width, the type of green space and the vegetation. The results of plant communities analysis is useful to analyze the ecological functions ability of public 
green space in Klojen Subdistrict, Malang City. The results of plant communities such as density, frequency and dominance will give the reasons why public open space is not able to produce oxygen or control the air temperature.

\section{The Analysis of Oxygen and Air Temperature Condition in Klojen Sub- District, Malang City}

1. Oxygen condition analysis in Klojen Sub-District

The ability of the ecological functions of green space as oxygen producer can be determined by comparing oxygen demand and oxygen production in public green space. Oxygen demand in Klojen Malang in this research will be calculated based on the needs of the population for oxygen as well as the need of vehicles for oxygen. $\mathrm{O} 2$ values used as the basis for the calculation is based on oxygen population consumption of $0,864 \mathrm{~kg} /$ person/day (Herliani in Sesanti, 2011). In addition, there is also a need for a motor vehicle component (P2KH Malang, 2012). Following is the oxygen demand in every village of Klojen, Malang City (see Tabel 2).

Tabel 2. Oxygen Demand in Every Village of Klojen Sub-District, Malang City

\begin{tabular}{clccc}
\hline No & \multicolumn{1}{c}{ Village } & $\begin{array}{c}\text { Population Oxygen } \\
\text { Comsumption } \\
\text { (kg/day) }\end{array}$ & $\begin{array}{c}\text { Oxygen Demand of } \\
\text { motor vehicles } \\
\text { (kg/day) }\end{array}$ & $\begin{array}{c}\text { Total Oxygen } \\
\text { Demand } \\
\text { (kg/day) }\end{array}$ \\
\hline 1 & Klojen & 5289,40 & 18988,8 & 24278,2 \\
2 & Samaan & 9348,48 & 33560,8 & 42909,28 \\
3 & Rampal Celaket & 5923,58 & 21265,5 & 27189,08 \\
4 & Kauman & 11886,04 & 42670,6 & 54556,64 \\
5 & Kidul Dalem & 5744,73 & 20623,4 & 26368,13 \\
6 & Kasin & 13401,50 & 48111,0 & 61512,5 \\
7 & Sukoharjo & 10251,36 & 36802,1 & 47053,46 \\
8 & Oro-Oro Dowo & 11797,92 & 42354,2 & 54152,12 \\
9 & Bareng & 18591,55 & 66743,2 & 85334,75 \\
10 & Gading Kasri & 12413,95 & 44565,8 & 56979,75 \\
11 & Penanggungan & 14782,17 & 53067,6 & 67849,77 \\
& Total & $\mathbf{1 1 9 . 4 3 0 , 7 2}$ & $\mathbf{4 2 8 7 5 3 , 0 3 9}$ & $\mathbf{5 4 8 1 8 3 , 7 6}$ \\
\hline
\end{tabular}

Source: P2KH Malang City 2012-2032

Based on these data, the highest oxygen demand is in Bareng village, while the lowest is in Klojen Village. As the number of people and vehicles in Bareng village are higher than in other villages, so that the oxygen demand is also high.

After knowing the oxygen needs, the next step is analyzing oxygen production in every Klojen subdistrict's public green space. The analysis used to determine the production of oxygen in green open space is based on biomass analysis. Measurements of biomass in the stands (trees) can be researched using allometric equations (Brown in Sutaryo, 2009). The equation will produce a value of biomass (dry weight), where 1 gram dry weight of plant is equivalent to 0.9375 grams/day (Gerakis modified by Wisesa in Ministerial reluation of PU, 
2008). Then the following equations are used to determine the production of oxygen by each stand (trees) in public green space.

$$
\begin{aligned}
& \mathrm{P} 0=\mathrm{Y} \times 0,9375(1000) \\
& \mathrm{PO} \quad \text { : oxygen production by trees } \\
& \mathrm{Y}: \text { Biomass (dry weight) of leaves vegetation }
\end{aligned}
$$

Based on the analysis the results can be seen in Tabel 3.

Tabel 3. Oxygen Production in Every Village of Klojen

\begin{tabular}{rlrr}
\hline No & \multicolumn{1}{c}{ Village } & Oxygen (Gram/day) & Oxygen (kg/day) \\
\hline 1 & Penanggungan & 5164112,0 & 5164,1 \\
2 & Samaan & 6647638,1 & 6647,6 \\
3 & Oro-oro Dowo & 18360757,1 & 18360,8 \\
4 & Rampal Celakat & 365523,0 & 365,5 \\
5 & Klojen & 1619290,2 & 1619,3 \\
6 & Kauman & 478789,7 & 478,8 \\
7 & Gading Kasri & 29269578,0 & 29269,6 \\
8 & Bareng & 1368259,1 & 1368,3 \\
9 & Kidul Dalem & 3400480,8 & 3400,5 \\
10 & Kasin & 16850691,0 & 16850,7 \\
11 & Sukaharjo & 0 & 0 \\
& Total & $\mathbf{8 3 5 2 5 1 1 8 , 9}$ & $\mathbf{8 3 5 2 5 , 1}$ \\
\hline & \multicolumn{2}{c}{ Source: writer, 2015 }
\end{tabular}

Based on Tabel 3, the village which has the highest production of oxygen is Gading Kasri village. While the production of the lowest oxygen is in Rampal Celakat village. In addition, there is one villages that did not have oxygen production, namely Sukaharjo village which not have public green space.

2. Analysis of oxygen conditions in Klojen Sub-Districts

One of the ecological functions of public green space is as an air temperature controller. Then to determine the ability of public green space as air temperature controller, the daily air temperature in every village and public green space of Klojen is required. Daily air temperature is the average observation for 24 hours measured every hour. In Indonesia, the average daily temperature can be calculated by the following equation (Tjasyono, 2004)

$$
\text { Daily Air Temperature }=\frac{2 T a+T b+T c}{4}
$$

Ta : Air temperature observation at 7.00 a.m.

$\mathrm{Tb}$ : Air temperature observation at 12.00 p.m.

Tc : Air temperature observation at 18.00 p.m. 
The daily air temperature then will be compared with the ideal of urban air temperature. According to Dahlan (2004), the convenience of a city in tropical areas such as Indonesia requires the ideal-medium of urban air temperature. The ideal-medium of urban air temperature is ranged between 22.5$27.5^{\circ} \mathrm{C}$. Based on the analysis, daily air temperature in every village of Klojen can be seen in Figure 2.

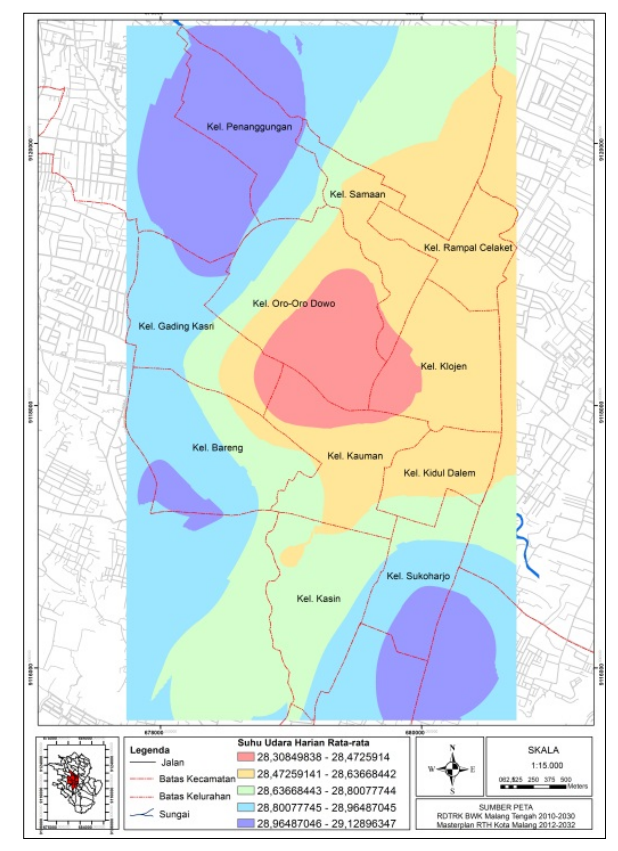

Figure 2. The Daily Air Temperature in Every Village of Klojen Sub-Districts Source: writer, 2015

Based on the image, the average daily air temperature in Klojen subdistrict's villages have diverse values. However, the values are not within the ideal air temperature range of urban areas, so when compared with the ideal urban air temperature, we can observe the air temperature needs in every village. Table 4 shows the air temperature needs in every village of Klojen subdistrict.

Based on Table 4, the daily air temperatures of Klojen subdistrict's village does not meet the ideal air temperature of a city. Various things can be done to lower the air temperature in Klojen, where one is by public green space. According to Kartasapoetra (2004), one of the things that affects the condition of the air temperature is the ground cover. Ground cover is soil that is covered by vegetation with a lower temperature than the soil without vegetation. 
Table 4. Air Temperature Needs in Every Village of Klojen SubDistricts

\begin{tabular}{|c|c|c|c|c|}
\hline No & Village & $\begin{array}{l}\text { Average Daily Air } \\
\text { Temperature }\left({ }^{\circ} \mathrm{C}\right)\end{array}$ & $\begin{array}{l}\text { Ideal-medium } \\
\text { air temperature } \\
\text { in a city }\left({ }^{\circ} \mathrm{C}\right) \\
\end{array}$ & $\begin{array}{c}\text { Air Temperature } \\
\text { Needs }\end{array}$ \\
\hline 1 & Penanggungan & 29,1 & $22,5-27,5$ & $-1,6$ \\
\hline 2 & Samaan & 28,5 & $22,5-27,5$ & -1 \\
\hline 3 & Oro-oro Dowo & 28,5 & $22,5-27,5$ & -1 \\
\hline 4 & Rampal Celakat & 28,6 & $22,5-27,5$ & $-1,1$ \\
\hline 5 & Klojen & 28,5 & $22,5-27,5$ & -1 \\
\hline 6 & Kauman & 28,4 & $22,5-27,5$ & $-0,9$ \\
\hline 7 & Gading kasri & 28,7 & $22,5-27,5$ & $-1,2$ \\
\hline 8 & Bareng & 29,0 & $22,5-27,5$ & $-1,5$ \\
\hline 9 & Kidul Dalem & 28,6 & $22,5-27,5$ & $-1,1$ \\
\hline 10 & Kasin & 28,6 & $22,5-27,5$ & $-1,1$ \\
\hline 11 & Sukoharjo & 29,2 & $22,5-27,5$ & $-1,7$ \\
\hline
\end{tabular}

Based on Tabel 4, it is necessary to know the condition of daily air temperatures from each public green space in Klojen. Table 5 display the daily air temperatures of public green space in Klojen.

Table 5. Condition of Daily Air Temperature in Public Green Space, Klojen Sub-Distric

\begin{tabular}{clccc}
\hline No & \multicolumn{1}{c}{ Public Green Space } & $\begin{array}{c}\text { Daily Air } \\
\text { Temperature }\end{array}$ & $\begin{array}{c}\text { Ideal-medium air } \\
\text { temperature }\end{array}$ & $\begin{array}{c}\text { The results } \\
\text { of analysis }\end{array}$ \\
\hline 1 & Jalur Tengah veteran & $27,6{ }^{\circ} \mathrm{C}$ & $22,5-27,5{ }^{\circ} \mathrm{C}$ & Not Ideal \\
2 & TMP Suropati & $27,9{ }^{\circ} \mathrm{C}$ & $22,5-27,5{ }^{\circ} \mathrm{C}$ & Not Ideal \\
3 & Segitiga Pekalongan & $28,6{ }^{\circ} \mathrm{C}$ & $22,5-27,5{ }^{\circ} \mathrm{C}$ & Not Ideal \\
4 & Taman Bundaran Bandung & $29,5{ }^{\circ} \mathrm{C}$ & $22,5-27,5{ }^{\circ} \mathrm{C}$ & Not Ideal \\
5 & Makam Samaan & $28,0{ }^{\circ} \mathrm{C}$ & $22,5-27,5{ }^{\circ} \mathrm{C}$ & Not Ideal \\
6 & Jalur Tengah J.A Suprapto & $26,8{ }^{\circ} \mathrm{C}$ & $22,5-27,5{ }^{\circ} \mathrm{C}$ & Ideal \\
7 & Hutan Kota Jakarta & $25,7{ }^{\circ} \mathrm{C}$ & $22,5-27,5{ }^{\circ} \mathrm{C}$ & Ideal \\
8 & Taman Simpang Balapan & $27,9{ }^{\circ} \mathrm{C}$ & $22,5-27,5{ }^{\circ} \mathrm{C}$ & Not Ideal \\
9 & Taman TGP & $27,7{ }^{\circ} \mathrm{C}$ & $22,5-27,5{ }^{\circ} \mathrm{C}$ & Not Ideal \\
10 & Hutan Kota Malabar & $25,4{ }^{\circ} \mathrm{C}$ & $22,5-27,5{ }^{\circ} \mathrm{C}$ & Ideal \\
11 & Taman Merbabu & $26,6{ }^{\circ} \mathrm{C}$ & $22,5-27,5{ }^{\circ} \mathrm{C}$ & Ideal \\
12 & Jalur Tengah Ijen & $27,6{ }^{\circ} \mathrm{C}$ & $22,5-27,5{ }^{\circ} \mathrm{C}$ & Not Ideal \\
13 & TMP Trip & $26,7{ }^{\circ} \mathrm{C}$ & $22,5-27,5{ }^{\circ} \mathrm{C}$ & Ideal \\
14 & Taman Median Basuki Rahmat & $28,3{ }^{\circ} \mathrm{C}$ & $22,5-27,5{ }^{\circ} \mathrm{C}$ & Not Ideal \\
15 & Taman Panglima Sudirman & $27,2{ }^{\circ} \mathrm{C}$ & $22,5-27,5{ }^{\circ} \mathrm{C}$ & Ideal \\
16 & Alun-alun tugu & $26,9{ }^{\circ} \mathrm{C}$ & $22,5-27,5{ }^{\circ} \mathrm{C}$ & Ideal \\
17 & Taman Ronggowarsito & $27,0{ }^{\circ} \mathrm{C}$ & $22,5-27,5{ }^{\circ} \mathrm{C}$ & Ideal \\
18 & Taman Trunojoyo & $26,6{ }^{\circ} \mathrm{C}$ & $22,5-27,5{ }^{\circ} \mathrm{C}$ & Ideal \\
19 & Taman Dr. Sutomo & $27,1{ }^{\circ} \mathrm{C}$ & $22,5-27,5{ }^{\circ} \mathrm{C}$ & Ideal \\
20 & Kompleks GOR Gajayana & $27,2{ }^{\circ} \mathrm{C}$ & $22,5-27,5{ }^{\circ} \mathrm{C}$ & Ideal \\
21 & Taman Adipura & $28,8{ }^{\circ} \mathrm{C}$ & $22,5-27,5{ }^{\circ} \mathrm{C}$ & Not Ideal \\
22 & Hutan Kota Kediri & $26,1{ }^{\circ} \mathrm{C}$ & $22,5-27,5{ }^{\circ} \mathrm{C}$ & Ideal \\
23 & Taman Melati & $28,1{ }^{\circ} \mathrm{C}$ & $22,5-27,5{ }^{\circ} \mathrm{C}$ & Not Ideal \\
\hline
\end{tabular}


Table 5. Continued

\begin{tabular}{|c|c|c|c|c|}
\hline No & Public Green Space & $\begin{array}{c}\text { Daily Air } \\
\text { Temperature }\end{array}$ & $\begin{array}{l}\text { Ideal-medium air } \\
\text { temperature }\end{array}$ & $\begin{array}{l}\text { The results } \\
\text { of analysis }\end{array}$ \\
\hline 24 & Jalur Tengah Galunggung & $26,7^{\circ} \mathrm{C}$ & $22,5-27,5^{\circ} \mathrm{C}$ & Ideal \\
\hline 25 & Jalur Tengah Dieng & $26,3{ }^{\circ} \mathrm{C}$ & $22,5-27,5^{\circ} \mathrm{C}$ & Ideal \\
\hline 26 & Taman WIlis & $27,2^{\circ} \mathrm{C}$ & $22,5-27,5^{\circ} \mathrm{C}$ & Ideal \\
\hline 27 & Kebun Bibit Garbis & $28,0^{\circ} \mathrm{C}$ & $22,5-27,5^{\circ} \mathrm{C}$ & Not Ideal \\
\hline 28 & Lapangan Dinas Pertanian & $27,9^{\circ} \mathrm{C}$ & $22,5-27,5^{\circ} \mathrm{C}$ & Not Ideal \\
\hline 29 & Taman Choirul Anwar & $27,4{ }^{\circ} \mathrm{C}$ & $22,5-27,5^{\circ} \mathrm{C}$ & Ideal \\
\hline 30 & Taman Kertanegara & $26,7^{\circ} \mathrm{C}$ & $22,5-27,5^{\circ} \mathrm{C}$ & Ideal \\
\hline 31 & Alun-alun Kota Malang & $26,9^{\circ} \mathrm{C}$ & $22,5-27,5^{\circ} \mathrm{C}$ & Ideal \\
\hline 32 & Makam Kasin & $26,8^{\circ} \mathrm{C}$ & $22,5-27,5^{\circ} \mathrm{C}$ & Ideal \\
\hline
\end{tabular}

Based on Tabel 5, there are some public green spaces that already have an ideal-medium urban air temperature. However, the air temperature may not be able to influence (let alone control) the temperature of the surrounding air either. Thus, the daily air temperature in public green space will be combined with daily air temperature in every village of Klojen Sub-Distric. This is done to determine the ability of public green space in controlling the air temperature.

\section{Ecological Function Analysis of Public Green Space Potential Development in Klojen Sub-Distric}

1. The ecological function of public green space as producer of oxygen.

Based on the analysis of oxygen conditions on the previous target, the results of oxygen demand and oxygen production as an every day value in Klojen has been obtained. From these results, the next step is to determine the ability of public green space in meeting oxygen needs. These results will be analyzed with scoring analysis to determine ecological function of public green space as a producer of oxygen. The scoring process is to divide the class capabilities of the ecological function as a producer of oxygen. The capability of public green space in every village of Klojen subdistrict as a producer of oxygen is presented in Figure 3.

Based on Figure 3 it can be concluded that there are no villages capable in meeting oxygen demand. However, there are six public green spaces that are quite optimal in producing oxygen. Therefore, each public green space in each village needs to be analyzed so that the ecological function can be more optimal. 


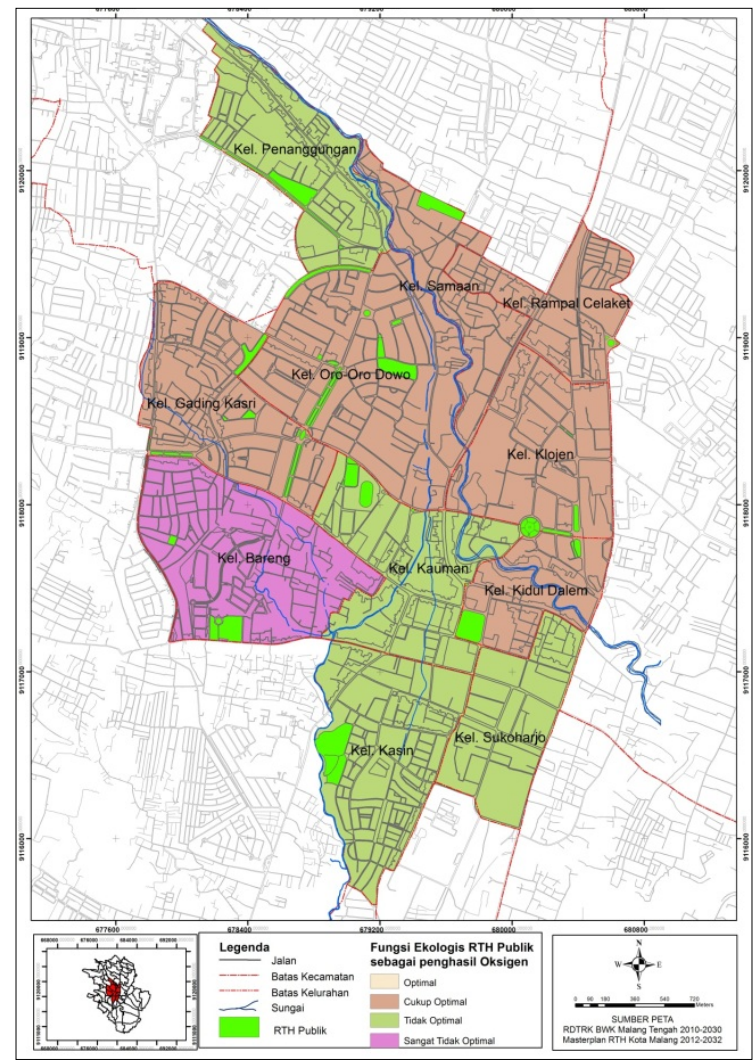

Figure 3. The Ecological Function of Public Green Space as a Producer of Oxygen Source: analysis result, 2015.

2. The ecological function of public green space as air temperature controller.

Based on the analysis of air temperature conditions previously, the results of daily air temperature in each village and public green space in Klojen SubDistrict has been obtained. Then to know the ecological function ability of public green space in controlling air temperature, the interpolation analysis was performed. Analysis of interpolation use krigging methods that will transform the data points about daily air temperatures in each village and public green space into spatial data. Results of this analysis will show whether the public green spaces were able to control the air temperature in each village. Based on the analysis, the result can be seen in Figure 4 below.

From this analysis, some public green space already have optimal controlling of air temperature, while other public green spaces are still not optimal in controlling air temperature. Therefore, some public green spaces need optimization in each village, corresponding with the characteristics that have been analyzed. 


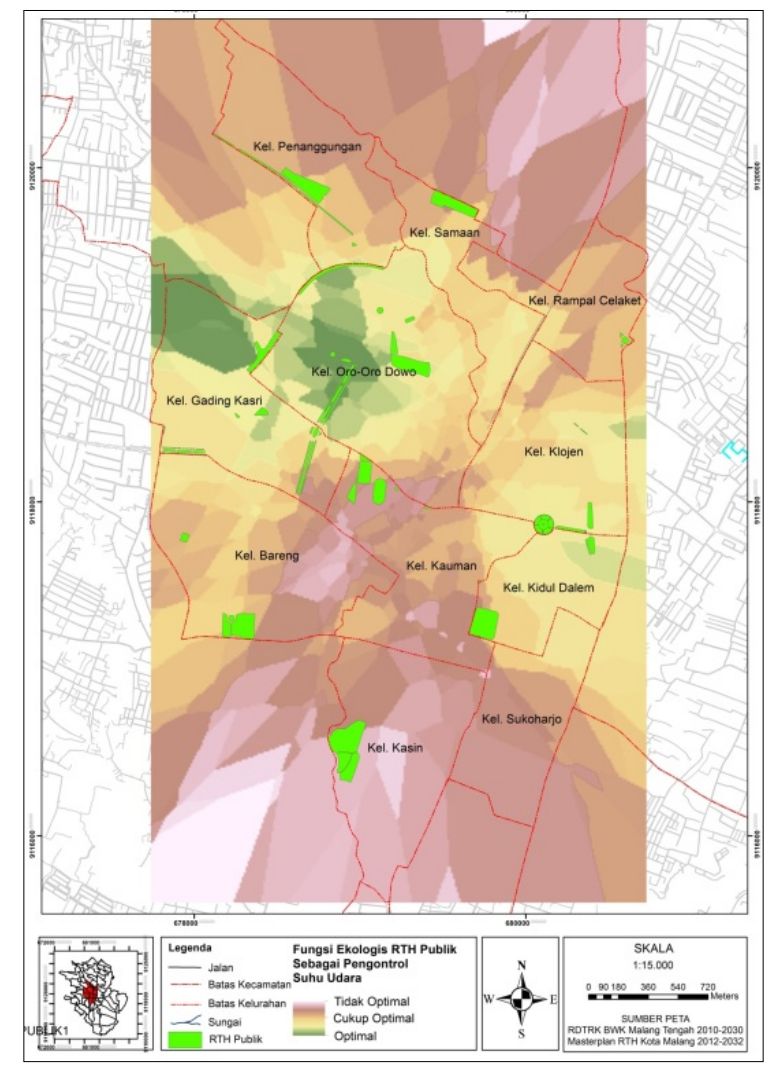

Figure 4. The Ecological Function of Public Green Space as Air Temperature Controller Source: Writer, 2015

\section{Optimization Concept of Ecological Functions in Klojen Sub-District's Public Green Space}

The concept of optimization is given for each public green space in Klojen, but not all public green spaces in Klojen require optimization. It is based on the previous target analysis, that there are some public green space that cannot be optimized. The public green spaces that do not require optimization are TGP Parks, middle paths (median) Galunggung, Trunojoyo Parks, Wildlife and Parks of Choirul Anwar, and also Bundaran Bandung Park. Optimization on these public green space is not possible because the characteristics do not support additional vegetation. Others public green spaces do need to be improved for their functioning.

Based on the analysis results, the optimization concept of ecological functions in Klojen subdistrict's public green space, Malang city, can be conclude; there are:

1. The addition of 1,216 trees to meet the oxygen needs of $195,648 \mathrm{~kg} /$ day. Additional criteria of tree such as:

a. Stratum B amounted to 129 trees

b. Stratum $C$ amounted to 815 trees

c. Stratum D amounted to 272 trees 
2. Criteria of diameter and crown width of vegetation adapted to the characteristics of each type of public green space.

3. Increase the value on plant communities frequency in every public green space according to criteria in each type of public green space.

4. Increase the density of plant communities in every public green space, according to criteria in each type of public green space

\section{CONCLUSIONS}

The final result obtained from this research is useful to optimize the ecological functions of public green space that already exists in Klojen. Result of the research shows that ecological function of public green space in Klojen subdistrict is not optimal. Neither the ecological function of public green space as an oxygen producer nor as an air temperature controller are optimal. The concept of optimization is to add 1,216 trees in which the criteria of vegetation have to meet the demanded characteristics of each public green space. Besides, increasing the values of frequency and density in each public green space are needed.

The unfulfilled oxygen demand in Klojen subdistrict is $464,658.5 \mathrm{~kg} /$ day. If the concept of optimization is applied to public green space in Klojen subdistricts, the producion of oxygen will increase $196,560.9 \mathrm{~kg} /$ day. This indicates the concept of optimization can reduce oxygen demand as much as $42.3 \%$. In addition, the ecological function of public green space as air temperature controller can be improved by decreasing the daily air temperature of public green space. The daily air temperatures of public green space can be lowered at least to the minimun of ideal urban air temperature, which is $27.5^{\circ} \mathrm{C}$.

The optimization basically can not cover all oxygen demand or lower the air temperature to reach the minimum ideal of urban air temperature. However, the concept of optimization relates to an ability of each green space so it can improve ecological function in Klojen Sub-District.

\section{REFERENCES}

Abdillah, J. (2005), Pola Penyebaran Taman Kota dan Peranannya terhadap Ekologi di Kota Jepara, Dissertation, Universitas Negeri Semarang, Semarang.

Bintariadi, B. (2010), Suhu Udara di Kota Malang Kian Panas, <http://www.tempo.co/read/news/2010/08/05/180269032/Suhu-Udara-di-Kota-MalangKian-Panas $>$ (Accessed on 25 April 2014).

Dahlan, E. N. (2004), Membangun Kota Kebun (Garden City) Bernuansa Hutan Kota, Bogor, IPB Press.

Ebtessam (2011), Evaluasi Kesesuaian Fisik dan Fungsi Ekologis Ruang Terbuka Hijau Lanskap CBD Sentul City Bogor, Institut Pertanian Bogor, Bogor.

Fandeli, C. (2004), Hutan Kota, Fakultas Kehutanan UGM, Jogjakarta.

Hakim, R. (2012), Komponen Perancangan Arsitektur Lansekap: Prinsip-Unsur Dan Aplikasi Desain, Bumi Aksara, Jakarta. 
Aini, Supriharjo, Sulistyarso: OPTIMIZING THE ECOLOGICAL FUNCTIONS OF PUBLIC GREEN SPACE IN KLOJEN SUB-DISTRICT, MALANG CITY

Hidayat, N. (2013), Pemkot Malang Dituding Salah Kelola Lingkungan, < http:/www.tempo.co/read/news/2013/06/05/206485980/Pemkot-MalangDituding-Salah-Kelola-Lingkungan> (Accessed on 25 April 2014)

Irwan, Z. D. (2005), Tantangan Lingkungan dan Lansekap Hutan Kota, Bumi Aksara, Jakarta.

Indriyanto (2012), Ekologi Hutan. Jakarta, PT Bumi Aksara.

Kartasapoetra, A. G. (2004), Klimatologi: Pengaruh Iklim Terhadap Tanah dan Tanaman, PT Bumi Aksara, Jakarta.

Pridhita, A. P. (2012), Arahan Pengembangan Ruang Terbuka Hijau Publik di Kecamatan Klojen Berdasarkan Persepsi Masyarakat, Universitas Brawijaya, Malang.

Sutaryo, D. (2009), Perhitungan Biomassa (Sebuah Pengantar untuk Studi Karbon dan Perdagangan Karbon), Wetlands International Indonesia Programme, Bogor.

Sesanti, N. (2011), Optimasi Hutan Sebagai Penghasil Oksigen Kota Malang, Tata Kota dan Daerah, 3(1).

Tjasyono, B. (2004), Klimatologi, ITB, Bandung. 